Language yesterday, today, tomorrow

Vol. I. No 12016

\title{
REVERSE PERSPECTIVE AS A NARRATIVE TECHNIQUE IN AMERINDIAN PROSAIC TEXTS
}

\author{
Svitlana Volkova
}

Volkova, S. Reverse perspective as a narrative technique in Amerindian prosaic texts // Lege artis. Language yesterday, today, tomorrow. The Journal of University of SS Cyril and Methodius in Trnava. Warsaw: De Gruyter Open, vol. 1 (1), June 2016. - p. 359-394. DOI: 10.1515/ lart-2016-0008 ISSN 2453-8035

\begin{abstract}
The paper focuses on the narrative perspective of interpreting the ethno-cultural meanings hidden in the characters of prosaic texts written by contemporary Amerindian writers (N.S. Momaday, Linda Hogan, Leslie Silko and others). The main idea raised in their works is to highlight ethno-cultural traditions, values, ceremonies and understanding the world. The main author's interest is paid to the reverse perspective as a narrative technique of interpretation the central character as ethno-cultural symbol.
\end{abstract}

Keywords: Amerindian prosaic texts, cognitive semiotic, cognitive narrative, linguistic and cognitive mechanism, linguistic and cognitive procedure, narrative perspective, reverse perspective.

\section{Introduction}

Interest in the nature of narrative dates back millennia, while a consistent theoretical consideration of the nature of narrative is the legacy of the formalist writings from the beginning of the twentieth century (Propp 1968), as well as the structuralist works of later years (Barthes, Todorov, Genette, and many others). All these theorists made progress in identifying a set of criterial features that define narrative, yet in earlier years, they tended to use fictional narratives as their main source of illustrative material, thus confining narrative understanding to a specific medium, namely, literary fiction. 
Nevertheless, narrative is directed to attract reader's attention and influence the reader's perception. Nowadays many narrative means and devices are explored. But nobody wanted to look inside the narrative content to reveal something meaningless and meaningful at the same time. By this, I mean the case when small detail at the beginning of the narrative may take on greater significance with a sense considered to be the most important in literary image making.

Consequently, the aim of this paper is to suggest the mechanism of reverse perspective as a narrative technique of interpretation the ethno-cultural meanings hidden in the text.

A handful of Native novelists - Navarr Scott Momaday (Kiowa), Leslie Marmon Silko (Laguna Pueblo), Louise Erdrich (Ojibwa), Linda Hogan (Chicksaw), James Welch (Blackfoot), and Gerald Vizenor (Ojibwa) - constitute the material of investigation. The plural nature of Native American literatures stems from the plurality of Native American cultures (Kiowa, Laguna Pueblo, Chicksaw, and so on) and the multiplicity of different genres (stories, novel-myth, novel-legend, essay, literary tale).

The history of Native American Literatures is often divided between works published before and after Navarr Scott Momaday's 1969 Pulitzer Prize for House Made of Dawn. Momaday's Pulitzer brought academic and public attention to Native writers. Lincoln states that it is not often, indeed seldom, that a writer word for word, character by character, action to action, story following story, surprises, upsets, delights, saddens, amazes a reader - as this one does (Lincoln 1985: 1). The floodgates opened up interest in a host of other contemporary Native authors as a result of Momaday's award. Lincoln refers to the period surrounding Momaday's achievement as a Native American Renaissance (Lincoln 1985: 11).

The Native American Renaissance took three forms: confidence on the part of contemporary Native authors in reclaiming their heritage in their own literary 
expressions; concern with finding and re-evaluating early literary works by Native authors; and renewed interest in anthropologies of translations of traditional artistic impressions - myths, prayers, ceremonies, rituals, love songs, oratory, etc. (Lundquist 2004: 38).

Many native authors contend that the deracinating conditions or behaviours resulting from colonization need not define Native people. Therefore, Native literary themes pivot around various descriptions and confrontations with the causes and effects of Native fragmentation, while at the same time imagining how healing from such debilitating fragmentation may occur. Consequently, Native writers share a common approach to: 1) the power of words and storytelling as instruments of survival including Trickster discourse; 2) the inseparable connection between identity and a sense of place - including the natural environment; 3) the importance of bloodlines (ancestry and posterity) - mixed or pure; 4) the perpetuation of powerful, often traditional, gender identities; 5) sexual expression used either to pervert or enhance human relatedness, and 6) the possibility of healing through reconciliation (Lundquist 2004: 203).

\section{Cognitive semiotics and the narrative perspective of the interpretation of ethno- cultural imagery}

Native American storytelling is imaginative and creative in nature. It is an act by which man strives to realize his capacity for wonder, meaning, and delight. It is also a process in which man invests and preserves himself in the context of ideas. Man tells stories in order to understand his experience, whatever it may be. The possibilities of storytelling are precisely those of understanding the human experience. 


\subsection{Cognitive Semiotics Perspective}

In cognitive semiotics, perspective literary image is identified as a sign, which incorporates different codes. Decoding them helps draw up their ethno-cultural implicatures, and to make the link between image, sign, and symbol.

As Silverman (1983) claims, "A symbol is a sign, which refers to the object that it denotes by virtue of a law, usually an association of general ideas, which operates to cause the symbol to be interpreted as referring to that object".

The symbols serve as connectors to certain powers; or they are, indeed, certain powers that need to be "activated" (Lake-Thom 1997: 37).

For instance, the circle is an ancient, primal symbol, or what Jung called a universal archetype. To the Native American, the symbol represents something that is sacred and holy. It represents unity, strength, protection, infinity, and spirituality. Thus, it is used in ritual, religion, art, architecture, ceremony, and social interaction. The following figure (fig. 1) depicts how Native myth and ritual function according to the cycles of Nature and life (see Fig. 1): 


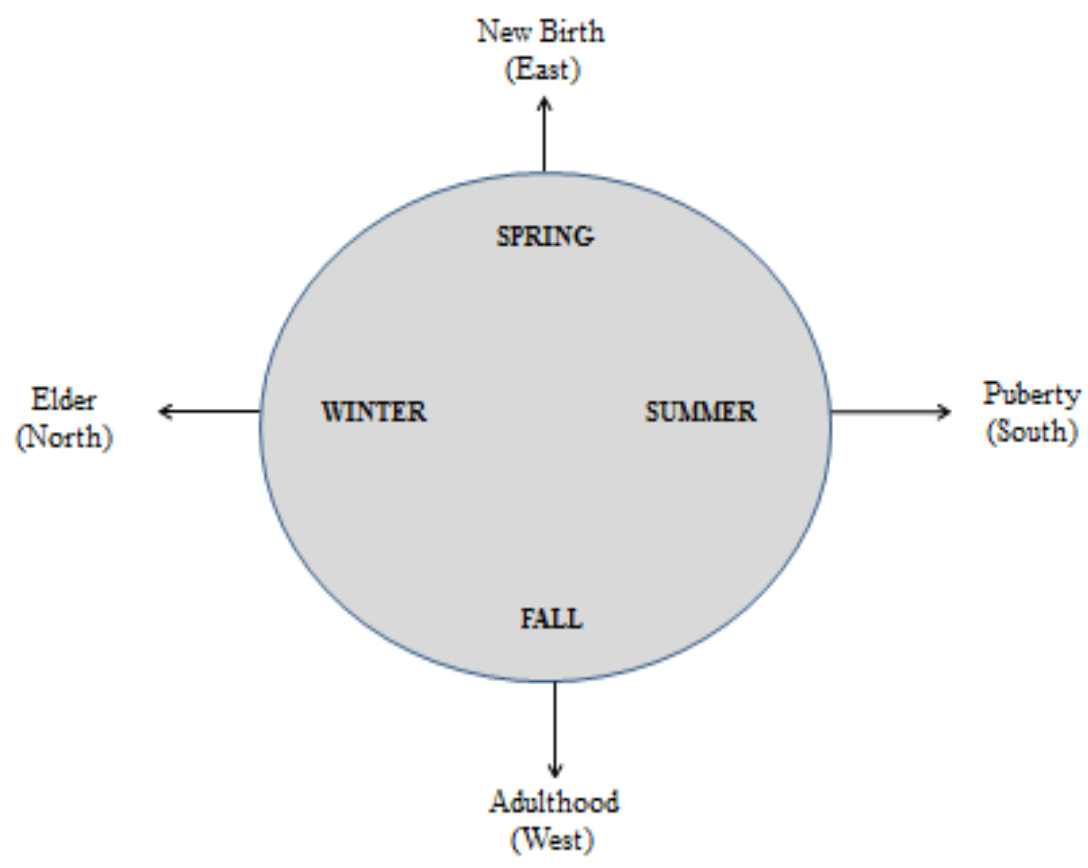

Figure 1. The Circle of Life

At each of stage of one's life, as with the four seasons of Nature, myth, ritual, and ceremony are used as a means of helping a person adjust to a new spiritual transformation. This transformation is celebrated both individually and collectively. It is right-brain-oriented, serves to develop intuitive skills, and in ancient times helped one achieve higher levels of accomplishment.

Symbols act powerfully, according to Sandner, to "change the psyche by converting energy into a different form, a form that can heal" (Sandner 1999: 14). Jung, in his analysis of numerous cultures, came to the conclusion that symbols act as transformers, their function being to convert libido from a 'lower' into a 'higher' form. This function is so important that feeling accords it the highest value (Sandner 1999: 15). This kind of psycho/social/spiritual healing processes thrusts patients into liminal space - a space where the sick person is willing to leave one mode of being (a death) and enter into another (a rebirth). 
In the novel-myth House Made of Dawn the central character (Abel) assumes his grandfather's place as a dawn runner, he is both chasing away evil (the night) and running toward re-creation (a new day). And such running exhausts - thrusting Abel into another dimension:

All of his being was concentrated in the sheer motion of running on, and he was past caring about the pain. Pure exhaustion laid hold of his mind, and he could see at last without having to think. He could see the canyon and the mountains and the sky (190).

The novel concludes: He was running and under his breath he began to sing. There was no sound, and he had no voice; he had only the words of a song. And he went running on the rise of the song. House made of pollen, house made of dawn. Qtsedaba (191)

In that ending/beginning Abel is a Pueblo dawn runner with the words of a Navajo healing ritual in his possession. And "Qtsedaba" is the Jemez formal marker indicating the end of a story. This moment is pre-empted (the end is told; but not the "there after"). "Pollen" symbolizes a creative potential, "Dawn" - the beginning of a new day, a new life, a new cycle of life. Nature symbols visualize the state of man character recreation.

Cognitive semiotics is based on the cognitive linguistics, which concerns the mental facilities the human being is born with - such as consciousness, memory, imagination, metaphorical reasoning and creativity - faculties that distinguish the human being from other species and that enable it to survive and thrive in the natural world (Sotirova 2016: 109).

On the focus of cognitive semiotics the paper investigates the properties of meaningful interactions with the surroundings across all domains of the natural as well as social world of the man character. Based on the cognitive semiotic approach it becomes understood that the symbolic meaning of the man or animal character of the text is 
created in every sense of the word, whether in perception, thought or language. In cognitive semiotics key we experience and find new insight by construing senses hidden in literary image. For instance, in the essay by Linda Hogan Dwellings we read: FOR YEARS I PRAYED FOR AN EAGLE FEATHERS. I WANTED one from a bird still living. A killed eagle would offer me none of what I hoped for. A bird killed in the name of human power is in truth a loss of power from the world, not an addition to it.

My first eagle feather, one light and innocent, was given to me by a traditional healer I'd gone to see when I was sick. He told me a story about feathers. When he was a child his home had burned down. All that survived in the fire were eagle feathers. They remained in the smoking ruins of their home, floating on top of black ash and water. The feather he gave me was one of those. I still keep it safe in a cedar box in my home (15-16).

The fragment above illustrates the use of the stylistic device called repetition: the word feather and its combination with the word eagle are repeated several times in such a short fragment of the text and hence they trigger the mechanism of accentuation of the reader's attention and activating the mental activity of the interpreter. If the word is repeated in the text more than twice it means that its semantic is much deeper than its denotative meaning.

The Guide to an Amerindian mythology (1991) provides some additional knowledge about the ethno-cultural meaning of eagle feather that can be used to construe a semiotic meaning of the symbol eagle feather: The eagle is the animal most sacred to the Native Americans. Because it flies higher than any other bird, it represents the Great Spirit. Eagle feathers are also highly prized and are used in ceremonial costumes, kachina doll decoration and head-dresses. It is said that if a person is holding an eagle feather in his hand, he cannot tell a lie. To the Chippewa people, the eagle is one of the Spirit Keepens of the Four Directions: Wabun of the East (Bryant 1991: 51). 
So, the eagle feather in the above fragment from the novel-essay is the sign, which implies ethno-cultural code: it manifests the Great Spirit. Repetition is the mechanism of forming image that signifies some special kind of knowledge incorporating this or that code. Decoding information hidden in its meaning allows for the identification of some symbolic meaning of literary image.

It often occurs in literary text that the symbolic meaning of a literary image may be extracted on account of all the descriptions (details) divergently given in a whole space of a text. Such literary image is cumulative (Kukharenko 2011). Its implicative features are explicated using both cognitive semiotics and narrative approaches at all the levels of literary text: surface representation (consisting of a text literary wording), text base (where the meaning of the text is represented as a network of concepts and propositions from the text), situational model (relations among items no longer depend on their structural features) (Kintsch \& van Dijk 1978: 390) and narration (the connection between narratives in the text).

\subsection{Cognitive narratology perspective}

Narrative interpretation of a literary image is directed towards collecting all the details, concerning its character, behaviour, deeds, relations with the other personages, to highlight its symbolic features. But the meaning does not lie in the surface of the text. To reveal/understand or extract the sense of the knowledge transformed in verbal signs the interpreter applies some cognitive operations such as mapping (projecting one motif into another), construal (selecting the appropriate structural possibility among various alternatives), inferences (making the conclusions from a set of premises), focusing (giving prominence to some selected elements of a scene and downplaying others). Hence, the operations of cognitive linguistics are applied in the narrative analysis of literary image. 
Cognitive narratology is the study of mind-relevant aspects of storytelling practices, wherever - and by whatever means - those practices occur. As this definition suggests, cognitive narratology is transmedial in scope; it encompasses the nexus of narrative and mind not just in print texts but also in face-to-face interaction, cinema, radio news broadcasts, computer-mediated virtual environments, and other storytelling media. In turn, "mind-relevance" can be studied vis-à-vis the multiple factors associated with the design and interpretation of narratives, including the story-producing activities of tellers, the processes by means of which interpreters make sense of the narrative worlds (or "story worlds") evoked by narrative representations or artefacts, and the cognitive states and dispositions of characters in those story worlds. In addition, the mindnarrative nexus can be studied along two other dimensions, insofar as stories function as both (a) a target of interpretation and (b) a means for making sense of experience a resource for structuring and comprehending the world - in their own right.

Mapping words onto worlds is a fundamental - perhaps the fundamental - requirement for narrative sense making. Such approaches as deictic shift theory (Duchan1995) and contextual frame theory (Emmott 1999) help reveal the complex cognitive processes underlying narrative ways of image making. They also suggest how configuring narrative worlds entails mapping discourse cues onto the WHAT, WHERE, and WHEN factors whose interplay accounts for the ontological make-up and spatiotemporal profile of a given story world. An approach based on shifting deictic centres indicates how narrative worlds are structured around cognitive vantage points that may change over the course of an unfolding story. Likewise, based on the assumption that characters will be bound into and out of particular contexts over time as well as the assumption that such contexts will be distributed spatially as well as temporally, Emmott's (1999) contextual frame theory points to the nexus of the WHAT, WHERE, and WHEN factors in narrative worldmaking. Reconsidered from a cognitive narratology perspective, earlier narratological scholarship can be read anew, 
providing further insight into the cognitive processes underlying the (re)construction of narrative worlds.

For instance, Chapter 2 'The Priest of the Sun' in House Made of Dawn starts with the description of helpless silversided fish: There is a small silversided fish that is found along the coast of southern California. In the spring and summer it spawns on the beach during the first three hours after each of the three high tides following the highest tide. These fishes come by hundreds from the sea. They hurl themselves upon the land and writhe in the light of the moon, the moon, the moon; they writhe in the light of the moon. They are among the most helpless creatures on the face of the earth. Fishermen, lovers, passers-by catch them up in their bare hands (79).

Further we read about Abel's feeling in 'other' world, his being at a loss, his regarding of his native world where he was at the centre: Now, here, the world was open at his back. He had lost his place. He had been long ago at the centre, had known where he was, had lost his way, had wondered to the end of the earth, was even now reeling on the edge of the void. The sea reached and leaned, licked after him and withdrew, falling off forever in the abyss. And the fishes ... (92).

These two abstracts are given separately and have no coherence at first glance. But it is the key word fish, which serves as trigger that activates the cognition of the interpreter and makes him think about some kind of connection between two narratives. So, mapping the state of fish on the state of man character explains the situation he encountered: in other world he feels like a small helpless fish.

Genette's (1979) influential account of time in narrative, for example, can be motivated as a heuristic framework for studying the WHEN component of world creation. When Genette distinguishes between simultaneous, retrospective, prospective, and 'intercalated' modes of narration (as in the epistolary novel, where the act of narration 368 
postdates some events but precedes others), these narrative modes can now be interpreted in light of the different kinds of structure that they afford for worldmaking. Retrospective narration accommodates the full scope of a story world's history, allowing a narrator to signal connections between earlier and later events through proleptic foreshadowing of the eventual impact of a character's actions on his or her cohorts. Simultaneous narration, in which events are presented in tandem with the interpreter's effort to comprehend the contours and boundaries of the narrated domain, does not allow for such anticipations-in-hindsight; rather, inferences about the impact of events on the story world remain tentative, probabilistic, open-ended (Margolin 1999). In short, classical, structuralist accounts suggest how a narrative world is "thickened" by forays backward and forward in time and throws into relief the processing strategies triggered by such temporal agglutination (Sternberg 1990; 1992; 2003).

When a text is written, technical choices must be made in view of producing a particular result in the story's verbal representation. In this way, the narrative employs distancing and other effects to create a particular narrative mood that governs "the regulation of narrative information" provided to the reader (Genette 1980: 41).

For Genette, a narrative cannot in fact imitate reality, no matter how realistic, it is intended to be a fictional act of language arising from a narrative instance. "Narrative does not 'represent' a (real or fictive) story, it recounts it - that is, it signifies it by means of language [...]. There is no place for imitation in narrative [...]" (Genette 1980: 43). Thus, in place of the two main traditional narrative moods, diegesis and mimesis, Genette contends that there are simply varying degrees of diegesis, with the narrator either more involved or less involved in the narrative, and leaving less room or more room for the narrative act.

In order to understand the contribution of narratology to semiotics, it is important to grasp the distinction between its three fundamental entities: story, narrative, and 
narration (Genette 1983: 2). The story generally corresponds to a series of events and actions that are told by someone (the narrator), and represented in some final form, producing a narrative. As a field of study, narratology looks at the internal mechanisms of narrative, the form taken by a narrated story.

Cognitive narrative analysis outlines the ways and means of narrative perspectives (prospective, retrospective, introspective) accentuating on the reverse perspective as the basic one in creating and interpreting man character as ethno-cultural image.

\section{Reverse perspective as a method of composition the objects in painting}

According to the rules of painting the objects placed at the foreground are larger in size than those at the background. Violation of this tradition leads to reverse perspective, which in its turn creates a closer objects are drawn as smaller. Such are the methods used for paying our attention to the objects of so called second plan.

These methods are all the more conscious in that they are, as it were, at odds with the usual colouring of objects and, consequently, cannot be explained as the naturalistic imitation of things as they normally are (Florensky 2002: 203).

For instance, the Sistine Chapel 'The Last Judgment' (Fig. 2). The Sistine Chapel is a large chapel in the Vatican City. It is renowned for its Renaissance art, especially the ceiling painted by Michelangelo, and attracts more than 5 million visitors each year. At the highest part of the ceiling, Michelangelo depicted nine scenes from Genesis, including "The Separation of Light from Darkness" at the altar end of the chapel to "The Drunkenness of Noah" at the other end. The most famous panels are "The Creation of Adam" and "The Fall of Man and the Expulsion from Paradise". Images of prophets and pagan sibyls surround the panels, and twisting (and originally controversial) male nudes decorate the corners. Breaking linear perspective in drawing 
the objects in the background of the picture of larger size attracts our attention and makes us think about symbolic meaning of those objects.

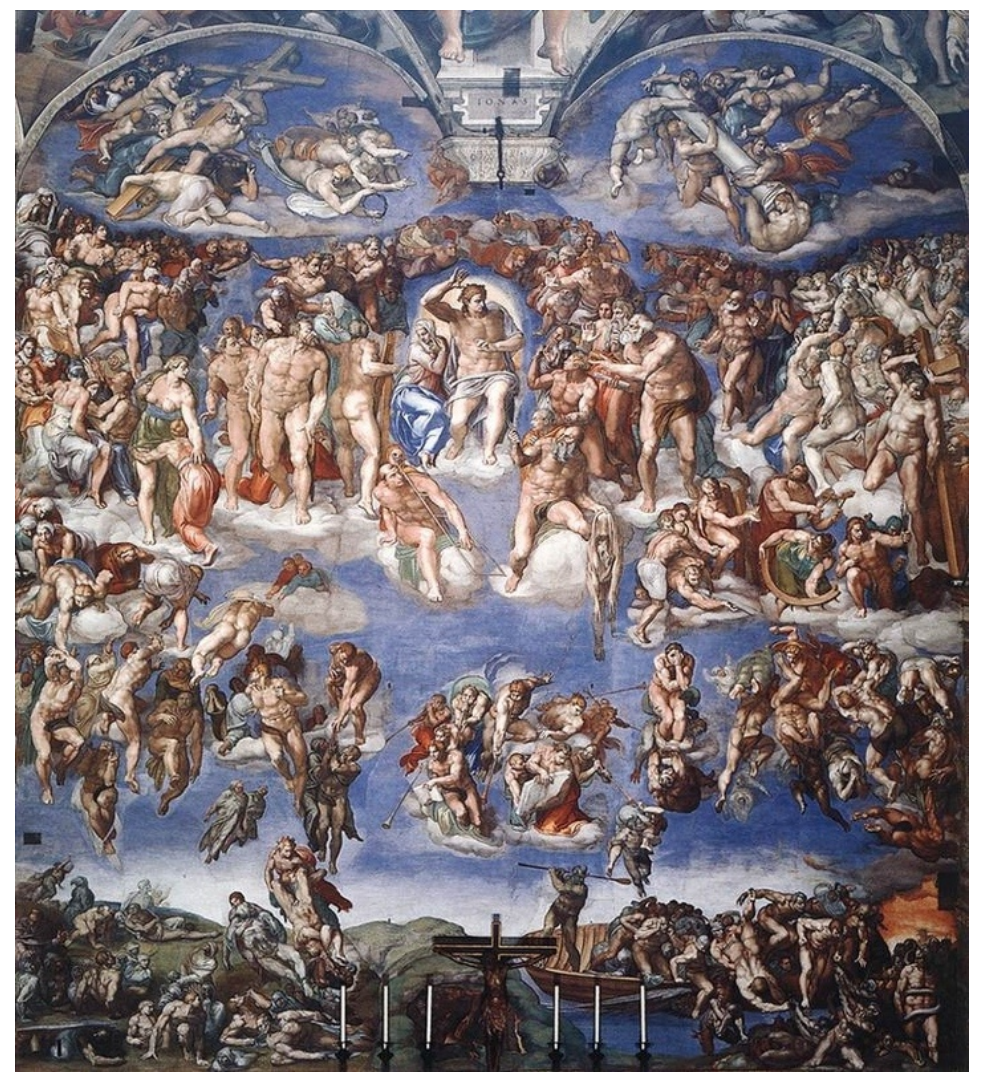

Figure 2. Reverse Perspective in Sistine Chapel 'The Last Judgment' (source: http://www.sacred-destinations.com)

I share Florensky's notion that it is a strange thing that 'illiteracies' of drawing, which apparently ought to throw any viewer who understands the 'obvious absurdity' of such a depiction into a rage, on the contrary arouse no such feelings of annoyance and are perceived as something fitting, even pleasing. When the viewer has the chance to put two or three icons from about the same period and painted with approximately equal skill side by side, he perceives an enormous artistic superiority in that icon, which demonstrates the greatest violation of the rules of perspective, whereas the icons, which have been drawn more 'correctly' seem cold, lifeless and lacking the slightest connection with the reality depicted on it (Florensky 2002: 202). It is very curious thing that the icons that are the most creative in terms of immediate artistic perception are perspectivally 'defective', whereas icons that better satisfy the perspective textbook are 
boring and soulless. If we forget the formal demands of perspectival rendering for a while, then direct artistic feeling it will lead everyone to admit the superiority of icons that transgress the laws of perspective.

Those who become acquainted with Russian icons of the fourteenth, fifteenth, and part of the sixteenth centuries for the first time are usually astonished by the unexpected perspectival relationships, especially in the depiction of objects with flat sides and rectilinear edges, as, for instance, buildings, tables, and chairs, and especially books, specifically the Gospels, which the Saviour and the saints are usually shown holding. These particular relationships stand in glaring contradiction to the rules of linear perspective, from whose viewpoint they can only be considered examples of crudely illiterate drawing (Florensky 2002: 201).

A rather illustrative example (Fig. 3) is provided by "Annunciation" (1405), a masterpiece of the Great Russian painter of Christian Orthodox icons and frescoes Andrei Rublev (1360-1429).

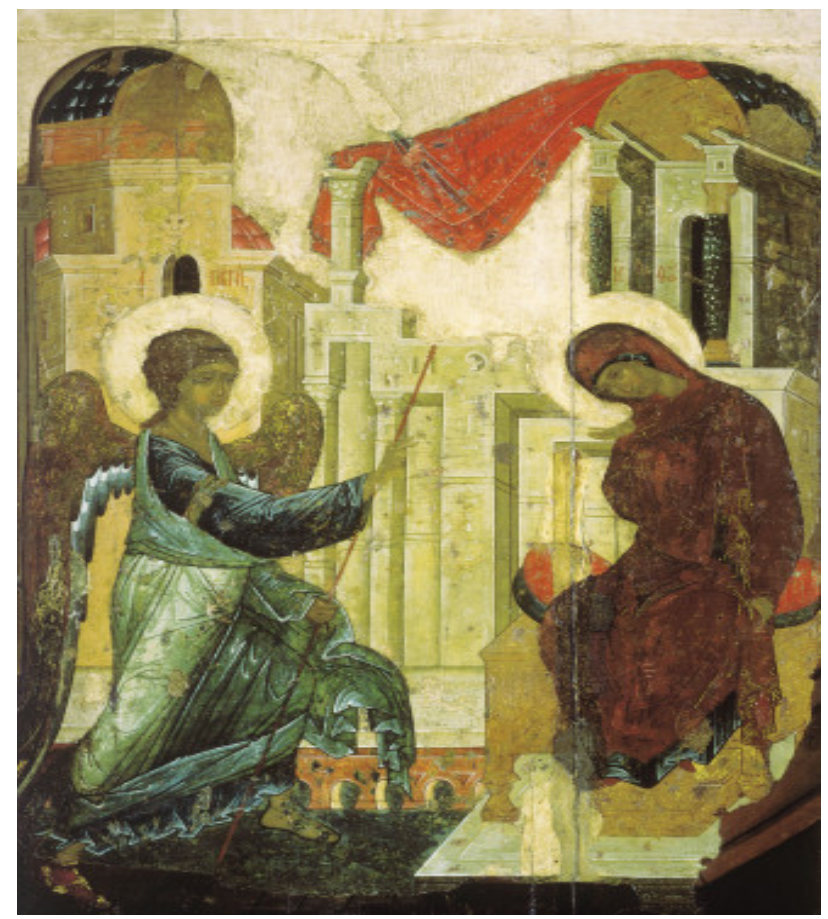

Figure 3. "Annunciation" by Andrei Rublev (source: http://www.wikiart.org) 
In the complex architectural structure of the background, a pattern of supposedly parallel lines converging towards the viewer is recurrent while in a detail of the upper left part of the picture, a building turns towards the viewer more faces than it ought to according to conventional linear perspective. The pedestal and the throne, upon which the Virgin Mary accepts from Archangel Gabriel the announcement of the miraculous conception, likewise display reversed perspective.

The methods mentioned above are generally termed reverse or reversed perspective, or sometimes also distorted or false perspective. But reverse perspective does not exhaust the varied peculiarities of an icon's drawing and also of its chiaroscuro. The closest dissemination of the methods of reverse perspective to be noted is the use of polycentredness in representations: the composition is constructed as if the eye were looking at different parts of it, while changing its position. So, for example, some parts of buildings are drawn more or less in line with the demands of ordinary linear perspective, but each one from its own particular point of view, with its own particular perspectival center; and sometimes also with its own particular horizon, while the other parts are, in addition, shown using reverse perspective. This complex elaboration of perspectival foreshortenings occurs not only in the depiction of buildings (palatnoepis'mo), but also in countenances, although it is usually applied without any great insistence, with restraint and moderation, and can therefore be passed off as 'mistakes' in drawing (Florensky 2002: 204).

Breakings the linear perspective or so called 'mistakes' in putting the objects in the space of a picture serve as triggers that emphasize the attention of the addressee and activates his cognition making him pay attention to those details and objects that are drawn incorrectly that is breaking the linear perspective. The signals of such triggers may be: size of an object, his place in the picture, color, proportions of the parts of an object, and so on. 
Accordingly it should be taken into consideration that the technique of reverse perspective in drawing foresees the presence in the space of the picture of such details, which serve to be triggers that cause addressee to have particular feelings and activate his cognitive processes in perception and understanding the sense of the objects presented in the picture.

Next step of the paper is applying the principle of reverse perspective used by masters of icons into the literary text in which main personage is interpreted as ethno-cultural symbol.

\section{Reverse perspective in literary text}

Semino states that literary text is a set of metaphors and narratives, which are central to how we make sense of and communicate our experience (Semino 2008). The idea can be developed into assumption that literary text is a set of narratives, which are central how ethno-cultural context of the text is formed.

Reading novel-myth House Made of Dawn (1998) and novel-legend The Way to a Rainy Mountain (Momaday 1969), novel Ceremony (Silko 1986), autobiographical novel Love Medicine (Erdrich 1993) and many other masterpieces produced by contemporary Amerindian writers opens the possibility of enlarging our knowledge about another culture, changing vision of life, worldview and interpreting the character in narrative in some different view point on him in order to characterize him as ethnocultural symbol.

Native American literature suggests options to many of dilemmas facing the multiple cultures within the borders of the United States. To know a culture "requires the learning of a whole new set of concepts, codes, patterns, and assumptions" (Toelken 1976 in Native American literatures 2004: 27). 
For instance, in Dwellings Hogan explains:

It has been my lifelong work to seek an understanding of the two views of the world, one as seen by native people and the other as seen by those who are new and young on this continent. It is clear that we have strayed from the treaties we once had with the land and with the animals. It is also clear, and heartening, that in our time there are many - Indian and non-Indian alike - who want to restore and honour these broken agreements (11).

In The voice in the margin: Native American literature and the Canon Krupat (1989) asserts "that Native American literary production, when we pay attention to it, offers texts equivalently excellent to the traditional Euro American great books. "It approves that these texts should be read not only in the interest of fairness or simply because they are available; nor it is because they provide charming examples of primitive survivals: they should be read because of their abundant capacity to teach and delight (Krupat 1989: 54).

Kerr, for instance, says that in writing House Made of Dawn Momaday was "seeking to make the modern Anglo novel a vehicle for a sacred text" (Kerr 1978: 173). Sacred texts, in this circumstance, are those texts, which deal with ultimate human concerns: time, suffering, loss, the power of language, the human ability to imagine, and the reorienting effect.

In the preface to the novel-myth House Made of Dawn (1998) Momaday writes:

A young Native American, Abel has come home from a foreign war to find himself caught between two worlds. The first is the world of his father's, wedding him to the rhythm of the seasons, the harsh beauty of the land, and the ancient rites and traditions of his people. But the other world - modern, industrial America - pulls at Abel, demanding his loyalty, claiming his soul, goading him into a destructive, compulsive cycle of dissipation and disgust. And the young man, torn in two, descends into hell. 
Reading these words it comes up the idea that there will be two narratives, each runs about different worlds the main hero finds himself in: native and the other one. The interpretation of the events, literary details and language highlights narrative triggers and lexical markers, which make coherence of these two narratives. In final it helps explain the main hero's behavior, his deeds, and intentions. Accordingly our task is to explain the linguistic and cognitive mechanism of reverse perspective in literary text, which is triggered by means of a key word (lexeme with symbolic meaning), word combination (stylistic figure or trope), and types of narration (description, thinking, inner speech, monologue, dialogue).

Applying the principle of reverse perspective onto linguistic interpretation of the text reverse perspective may be regarded in two dimensions: 1) as author's narrative technique of forming mytholoric image by means of cumulating literary details divergently put in the space of the text and 2) as analyst's technique of interpetation the ethno-cultural sense of a literary image. In the paper I pay more attention to reveal its character from interpreter's point of view.

\subsection{The linguistic and cognitive mechanism of reverse perspective}

Reverse perspective in narrative is a method that marks an important milestone in the development of central character as ethno-cultural symbol. Reverse perspective in literary text is something different from retrospective narration defined by Genette. Retrospective means that narrative is broken by some other narrative, which has reference to the past events happened with the hero. This 'other narrative' introduces some additional information and is linked with the main narrative with a key word.

To explain the mechanism of reverse perspective in narrative (Fig. 4) it should be understood that the text manifests one space with different levels, different images, and different textual worlds. 


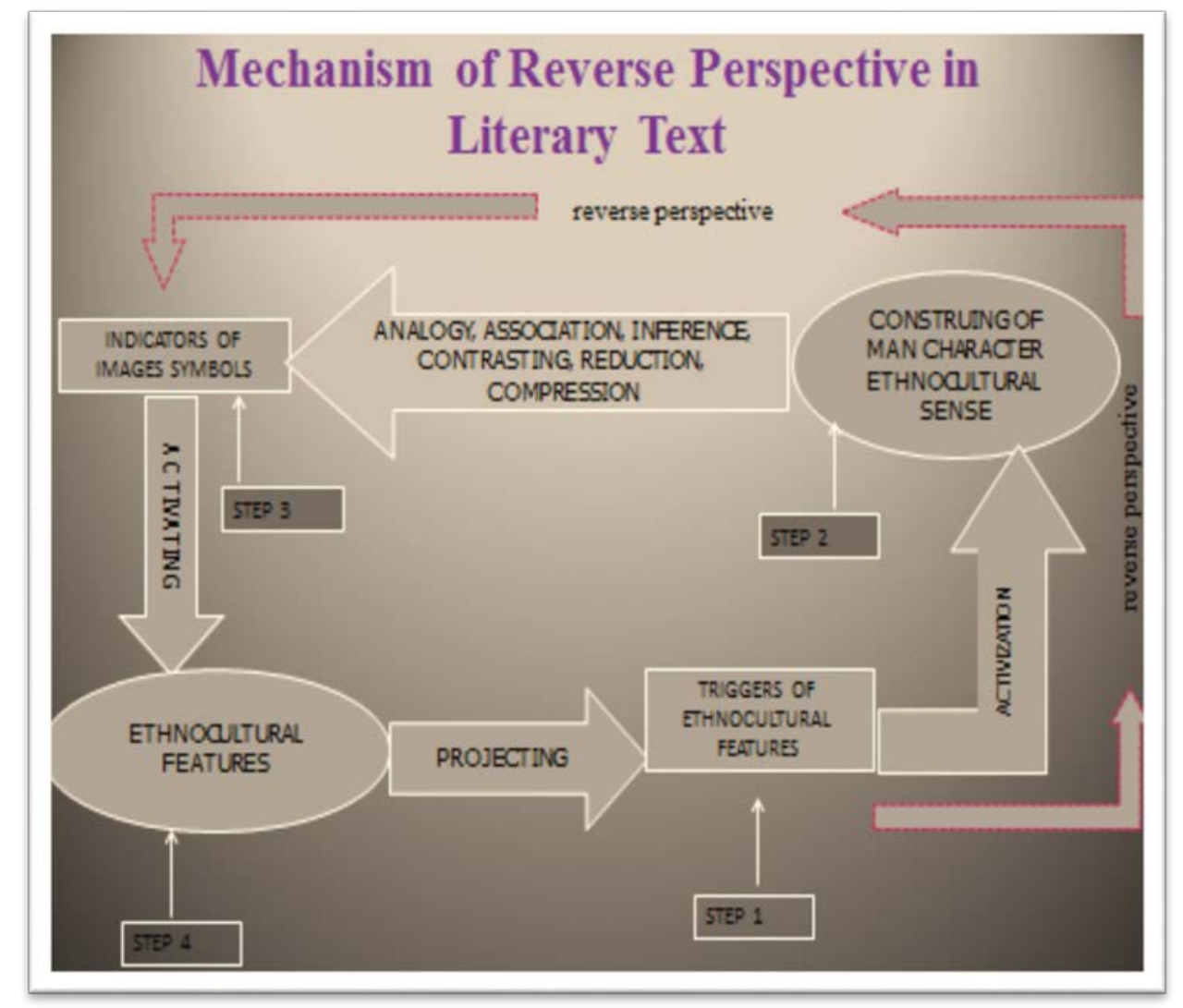

Figure 4. The mechanism of reverse perspective in literary text

Different textual worlds are interconnected. The interpreter cannot understand the type of their interconnection at first glance. But applying such mechanisms as association, analogy, compression, and so on he tries to find some similar facts, objects, small details to map one event onto another and in such a way to explain the deeds and behaviour and, what is the most important, to reveal hidden meaning, which allows to identify the man character as image-symbol. Reverse perspective is the means of interpretation as it is triggered by key word that is repeated in different fragments of the texts.

To understand the connotative meaning of a word trigger let's refer to Macmillan English Dictionary (2002), which gives such its definition: as a noun 1) the part of a gun that you move with your finger to make the gun fire; 2) something that produces an immediate result; as a verb 1) to make something happen; 2) to cause someone to 
have particular feelings or memories; 3) to cause someone to do or say something, as trigger a response / reaction (Macmillan English Dictionary 2002: 1537).

Narratives may be of two forms: narrative types and narrative kinds (Brandes 2004; Vinogradov 1963). Among types of narrative there are distinguished description, telling, comment, thinking, argumentation, and narrative kinds include inner speech, monologue, and dialogue.

In the first narrative situation (Fig. 4 step 1) we underline the triggers of ethno-cultural features embedded in a central character: They [Abel and white man] went out into the rain and darkness. All around was silence, save for the sound of the rain and the moan of the wind in the wires. Abel looked at him with eagle eyes. He stood as if he were male eagle watching from the very top of a mountain. The white man raised his arms as if to embrace him. Then he closed his hands upon Abel and drew him closer. Abel felt the blue shivering lips upon him, felt even the scales of the lips and the hot slippery point of the tongue, like a snake's sting. He was sick with terror and revulsion, and he tried to fling himself away, but the white man held him close. The hands of the albino lay as if silver rope curving Abel's throat. In his terror Abel leaned inside the white man's arms and drove the knife up under the bones of the breast and across. Abel threw down the knife and the rain fell upon it and made it clean (House Made of Dawn, p. 73-74).

The number of comparisons, based on linguistic and cognitive operations of analogy, association, with their key lexemes (eagle and snake), which are verbal images with symbolic meaning help us construe male characters as ethno-cultural symbols (Fig. 4 step 2). Abel is associated with Eagle (looked with eagle eyes, male eagle) and his deed is approved as, at the end of this narrative, the rain as symbol of purification 'fell upon it [the knife] and made it clean', while the actions of white man are compared with those of the snake (as if to embrace him, like a snake's sting). 
The comparisons become triggers of reverse perspective. To interpret the semiotic sense of them we should return to the very beginning of the novel when male and female eagles' flight is described and followed by the narrator's running commentary on their killing a black rattlesnake (Fig. 4 step 3): They were golden eagles, a male and a female, in their mating flight. She carried a black rattlesnake, it hung shining from her feet. And then she let it go. It fell slowly, writhing and rolling, floating out like a bit of silver thread against the wide backdrop of the land. First the male eagle let the carrion drift by; then suddenly he hit the snake in the head, crackling its long body like a whip. At the top of his glide he let go of the snake. Abel watched the eagles go. It was an awful, holy sight, full of magic and meaning (House Made of Dawn, p. 16).

In the abstract, which highlights one of the animal life events the words eagles and snake are repeated several times. Lexical repetition makes us turn to a Guide to Native American Nature Symbols, Stories and Ceremonies (Lake-Thom 1997) to learn how to interpret good and bad signs, their symbolic meaning embedded in these verbal images: "Eagles are always very special and good signs. They represent protection, wealth, wisdom, foresight, strength, and spirituality" (Lake-Thom 1997: 109); "The Rattlesnake can be used for good or bad power. The Rattlesnake that is predominantly black in color is a bad power" (Lake-Thom 1997: 153). So, the interpretation of that 'holy sight' described in the given above abstract leads to the revelation of the following symbolic meaning: The Good (Eagles) destroys the Evil (Black Rattlesnake).

The two narratives have equivalent syntactic constructions structure (he hit the snake in the head SPOA = Abel drove the knife up under the bones of the breast SPOA), stylistic comparative device (like a bit of silver thread, as if silver rope, like a snake's sting), common motif (the fight between Good and Evil in which Good is the winner). 
Symbols verbalized in the text may be repeated not only within one text of the author but serve as triggers of reverse perspective in some works by the same author. For, instance, bats in Dwellings and Mean Spirit by Hogan: Bats hear their way through the world. They hear the sounds that exist at the edges of our lives. Leaping through blue twilight they cry out a thin language, and then listen for its echo to return. The world throws back a language; the empty space rising between hills speaks an open secret then lets the bats pass through, here or there, in the dark air. Everything answers, the corner of a house, the shaking leaves on a wind-blown tree, and the solid voice of bricks (Dwellings 25-26).

In Mean Spirit bats become a symbol for earth consciousness - a tangible symbol of the possibility that the world speaks if we know how to listen to him: He finds a mummified body and realizes this space is also a burial site. He finds rock art on the walls - paintings of red bats, blue fish, black buffalo. It was a sacred world they entered and everyone became silent and heard a distant dripping of water in the cave ways, the echoing sounds of the breathing earth (Mean Spirit 284).

\section{Retrospection (flashback), prospection (flash-forward) and reverse perspective} This chapter sets out to discuss narrative techniques (retrospection, prospection, and reverse perspective), which are characteristic for postmodernist narrative with its metafiction, fragmentation, ontological concern, temporal distortion. Retrospection or flashback, prospection or flash-forward and reverse perspective or cognitive semiotic bridge between different narratives in the text help create the manifoldness of such text semantic concepts as Human Being, Time, and Space (Kukharenko 1988: 74).

Retrospection or "travelling to the past" returns to the events happened in the previous narrative of the text and is denominated as flashback. 
Prospection can be conceived as foreseeing future events (Galperin 2007: 105-112). It states what information and in what sequence is to come in the course of narration on a certain subject. A widely used term is flash-forward or anticipation of events. So, the main function of prospection in the text is factual, that is to make a project onto further events.

For instance, in House Made of Dawn the embedded text of the legend about Santiago performs factual function as it foresees the following events describing the Maize Feast holding in modern society: Santiago rode southward into Mexico. He rode on for many days, and at last he came to the royal city. That day the king proclaimed that there should be a great celebration and many games, dangerous contests of skill and strength. Santiago entered the game. He was victorious, and as a prize he was allowed to choose and marry one of the king's daughters. But the king directed that Santiago should be put to death. When soldiers turned upon Santiago, he slew them with a magic sword. At the end of the journey Santiago had no longer any need of his horse, and the horse spoke to him and said: "Now you must sacrifice me for the good of the people". After that the rooster spoke to Santiago and said: "Now you must sacrifice me for the good of the people". And accordingly Santiago tore the bird apart with bare hands and scattered the remains all about on the ground. The blood and feathers of the bird became cultivated plants and domestic animals, enough for all the Pueblo people (35).

Main narrative continues with a line spacing from the text of a legend given above: The late afternoon of the feast of Santiago was still and hot, and there were no clouds in the sky. It was a pale midsummer day, two or three hours before sundown. When they came to the Middle, there was a lot of sound going on... (36).

Next sample is from Dwellings by Hogan: In 1981 a cave was discovered that contained burnt offerings of red ocher, while clay, sewing needles of bone, and a stone carving thought to be a deity. On one side of it was the face of a man. On the other was 
the face of a lion. These were thought by the archaeologists to be representations of two natures - good and evil. They didn't say which was which. But it took me back to that day, travelling with my father. Years have passed; we have changed. He would understand that lion now, having grown old and returned to the inner world of his own self, as strong men do in their passage through life. There was something deeper than human that day. I think now, something of the world of myth. Now we are no longer at the divide, the place of separation. He would say now, I know, that a lion inhabits the cave (34).

The relaxation of strict time lines or discontinuous time is the marker of prospection as well as retrospection technique. There is no clear border between several events occurring simultaneously: 'In 1981' and 'Now we are no longer...'. It is left to the reader to 'create a time line', which might be disrupted later by the author. This technique is referred to by Jameson as schizophrenia (Galens 2002: 254).

Prospection and retrospection interrupt the content connection of two utterances (narratives) standing in a position of close contact. However, thanks to the precise cohesion and coherence of the text a particular fragment of the text fluently flows into a textual net and forms a semantic bridge which connects the previous and the following narration.

One of the signals of prospection is a change of the grammatical tense indication. Lexical indicators are widely used as well. Information, which appears to be prospective is presented in detail in the forthcoming narrative. It is common for prospective episodes not to be very extensive. Thus, prospective information is only mentioned and is revealed for the reader later. That is why a return to the interrupted continuum causes no difficulty to the reader. 
Retrospection, unlike prospection, usually leads the action from the current time of the plot to the past. Sometimes the current time of the plot serves only as the frame for narration-recollection.

In Painted Drum by Erdrich narration is given in fragments one breaking the other. Different narratives juxtapose in order to give some additional information.

So, the main narrative ends with the words: This very pipe. This is the one he smoked with those everlasting trees (168).

Further, with a line spacing, it runs about past events: The day that my grandfather, Albert, and his boy, whose nickname was Chikie, went out to visit the trees, new leaves were just unfurling. A light breeze gave no hindrance. There was warm sun, a clear sky. Best of all, no zagimeg and no biting flies. The three paddled all morning, ate their lunch of grease and bannock and tea on a flat gray rock, and continued on into the afternoon, until they reached the place where they thought the trees were (168).

If compare these two fragments it is seen that the first narrative has the marker of present time and the second one has the marker of past time. They have semantic connection by means of the word tree, which is an activator of some regards in the mind of narrator.

It should be stressed that though prospection and retrospection are breakers of the narrative, nevertheless they are given as embedded fragments in accordance to main narrative. Prospective and retrospective fragments of the text have their lexical and grammatical markers different from those in main narrative, but they are included in order to give some additional information. 
Reverse perspective is another kind of narrative technique as there is no breaking of main narrative. Reverse perspective as semantic bridge makes it possible to project the sense of one event onto the other and hence connect them semantically. So, fragments which are joined semantically may be both close and far from each other in the text. For instance, in Dwellings by Hogan we read: In earlier days, before the springs and caves were privately owned, they were places of water healing for Indian people, places where conflict between tribes and people was left behind, neutral ground, a sanctuary outside the reign of human differences, law, and trouble. Men and women travelled across the wide green plains, down the red mountains and rounded hills, to rest inside earth's cauldron (29-30).

One of the Indian women talks about water medicine. She was sick and had lost her faith in the medicine ways, she says, and has come back to the healing waters of the earth. We are welcome here. I love this inner earth, its murmuring heartbeat, the language of what will consume us. Above is the beautiful earth that we have come from. Below is heat, stone, fire. I am within the healing of nature, held in earth's hand (35).

In the second fragment our attention attracts the expression healing water. And it's not clearly understood: Why are we welcome here? What for? Then we return to the legend about healing places and come to know that there were water healing places without conflict, separating the land between Indian people and New World people, but it was freedom and harmony between man and nature.

Essay Dwellings by Hogan is a set of different stories about human being, nature, relationship between them, the origin of person and animals, and their functions, and so on. In the narrative the author describes symbols, which are of cultural importance for this or that tribe. Narrative structure analysis allows making a model of narration with the domain narrative technique of reverse perspective (Fig. 5). 


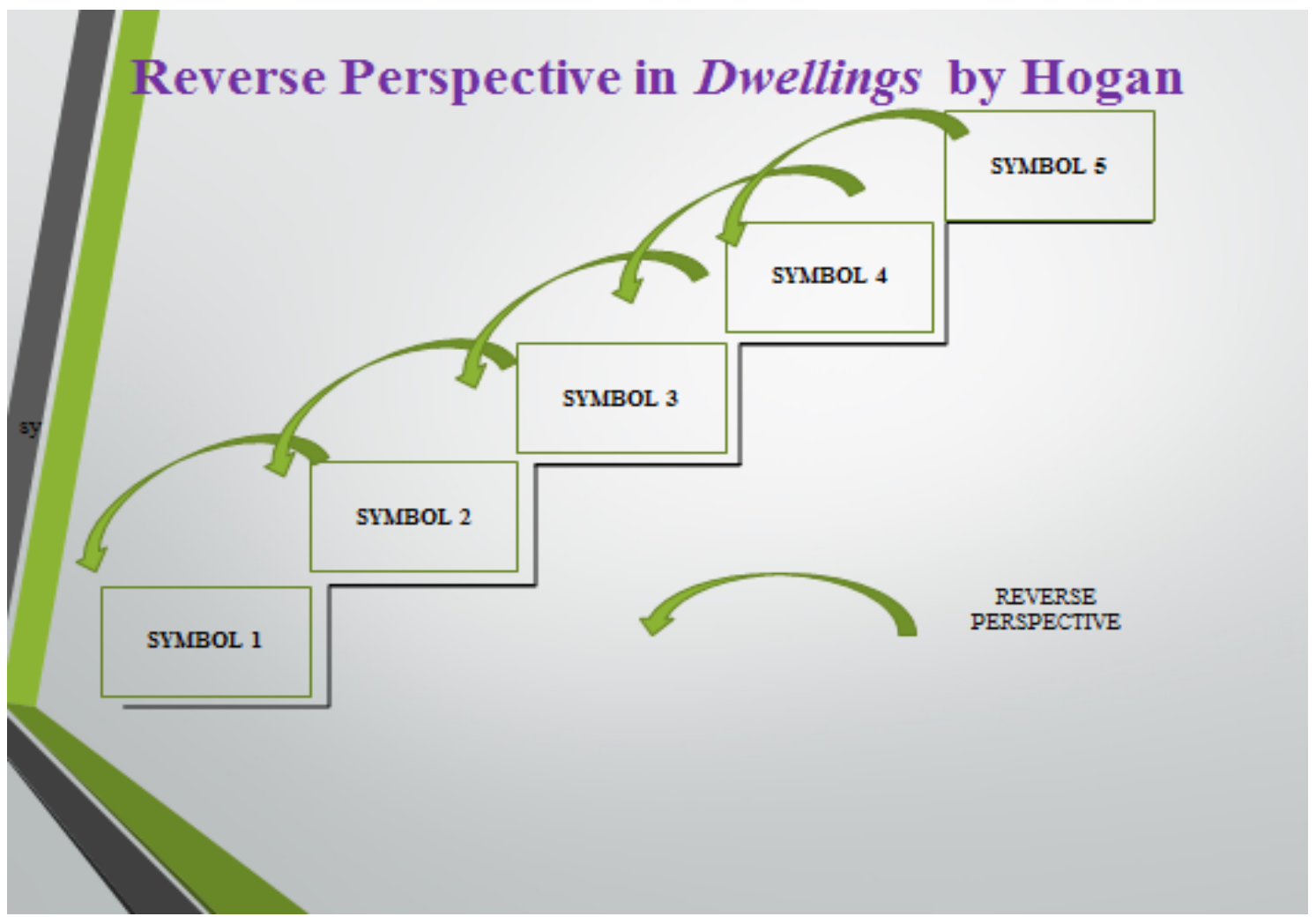

Figure 5. Reverse Perspective in Dwellings by Hogan

\section{Discussion and conclusion}

In the book The pleasure of the text (Barthes 1975) Barthes declares the choice between pleasure and the more ravaging term to be precarious, revocable, the discourse incomplete, but of course he cannot come up with "coming", which precisely translates as what the original text can afford: ideological structures, intellectual solidarities, the propriety of idioms, sacred armature of syntax. It is a powerful gush of words, a ribbon of infra-language (Barthes 1975: 7). Interpreting this 'gush of words' may be possible if we read the text not only for deriving pleasure from it, but also for revealing invisible meanings hidden in its narrative structure. So, cognitive linguistics approach to interpretation of the text is just the focus combining semantic, semiotic, syntactic, and narrative analyses.

Cognitive linguistics, in its insistence that language is a phenomenon of the mind and can therefore only be properly understood in relation to the mental processes of which 
it is a manifestation, is a radical rejection of linguistics and its modular view of language as practised for much of the twentieth century from Saussure to Chomsky.

Langacker (1990) in his article Introduction to Concept, Image, and Symbol writes: "Lexicon, morphology, and syntax form a continuum of symbolic units, divided only arbitrarily into separate components; it is ultimately as pointless to analyze grammatical units without reference to the semantic value as to write a dictionary which omits the meanings of its lexical items" (Langacker 1990 in Cognitive Linguistics: Basic Readings 2006: 29). It may be only added that lexicon, morphology and syntax form a continuum of symbolic signs in a narrative structure of literary text.

Today's readers are no longer passive receivers of an author's constructed world. They are instead supposed to participate and take an active role in ascertaining a text's meaning before them, to ruminate on the plausible interpretations of a given narrative so as to work things out for themselves.

Every text is a system of signs organized according to codes and subcodes, which reflect certain values, attitudes, beliefs, assumptions and practices (Chandler 2007: 157). Codes transcend single narratives, linking them together in an interpretive framework, which is used by their producers and interpreters. In reading texts, we interpret signs with reference to what seem to be appropriate codes. Textual codes do not determine the meanings of texts but dominant codes do tend to constrain them. In the paper the dominant code is considered to be ethno-cultural one, which greatly influenced the revealing ethno-cultural meanings hidden in those verbal signs that describe the characters, interests, beliefs of man, and animal characters.

This is the case with Amerindian writers' prosaic texts, expecting the readers to be active participants, to cooperate with the author during the reading process in creating the narratives' meanings. They have made use of strategies and techniques that both 
violate readers' expectations, and simultaneously invite them not to sit passively before the text. By employing techniques and strategies, which are associated with postmodern fiction writers seek to present different contradictory outcomes for events on the one hand, and to accentuate the ethno-cultural values and concepts on the other.

Text is a set of narratives, in which verbal signs imply different information about signified object. Postmodernist narrative incorporates modes of narration which at once departs from traditional ways of depicting events. The study highlights prospection, retrospection and reverse perspective as narrative techniques peculiar for postmodern prosaic texts. Special scientific attention is paid to the technique of reverse perspective, which helps connect similar plots and structures, predictable situations, episodes, conflicts and resolutions, and finally construe ethno-cultural sense of central character. Linguistic and cognitive mechanism of reverse perspective is based on repetition, parallelism, similarity, analogy.

\section{References}

Barthes, R. (1975). The pleasure of the text. New York: Hill and Wang.

Brandes, M. (2004). Text stylistics. Theoretical course. Moscow: Progress.

Bryant, P. (1991). The aquarian guide to Native American mythology. London: The Aquarian Press.

Chandler, D. (2007). Semiotics: the basics. London and New York: Library of Congress.

Duchan, J. (1995). Deixis in narrative: A cognitive science perspective. Hillsdale: Lawrence Erlbaum.

Emmott, C. (1999). Narrative comprehension: a discourse perspective. USA: Oxford University Press.

Eldrich, L. (1993). Love medicine. N.Y.: Henry Holt and Company.

Eldrich, L. (2005). The painted drum. N.Y.: Harper Collins Publishers Limited.

Macmillan English Dictionary for Advanced Learners (2002). Oxford: Macmillan. 
Florensky, P. (2002). Beyond vision: essays on the perception of art. London: Reaktion Books.

Galens, D. (2002). Literary movements for students, Vol. 3, US: Gale Cengage Learning.

Galperin, I.R. / Гальперин И.P. (2007). Текст как объект лингвистического исследования. Москва: КомКнига.

Geeraerts, D. (2006). Cognitive Linguistics: Basic readings. Berlin-New York: Mouton de Gruyter.

Genette, G. ([1979] 1983). Narrative discourse: an essay in method. Ithaca: Cornell University Press.

Hogan, L. (2000). Mean spirit. N.Y.: The Ballantine Publishing Group.

Hogan, L. (2001). The woman who watches over the world. N.Y.: W.W. Norton and Company.

Hogan, L. (1995). Dwellings. N.Y.: A Toughstone Book.

Kerr, B. (1978). The novel as sacred text: N. Scott Momaday's Myth-Making Ethic. In Southwest review, 63, p. 172-179.

Kintsh, W. \& van Dijk, T.(1978). Toward a model of text comprehension and production. In Psychological review, 85, p. 363-394.

Krupat, A. (1989). The voice in the margin: Native American literature and the canon. Berkeley: University of California Press.

Kukharenko, V.A. / Кухаренко В.А. (2011). Интерпретациия текста. [3-е изд, испр.]. Одесса: Латстар.

Lake-Thom, B. (1970). Spirits of the Earth: a Guide to Native American Nature Symbols, Stories and Ceremonies. New York: Penguin Group.

Langacker, R. (1990). Concept, image and symbol. In Cognitive linguistics: Basic readings. Berlin-New York: Mouton de Gruyter.

Lincoln, K. (1985). Native American renaissance. California: University of California Press.

Lundquist, S. (2004). Native American literatures: an introduction. New York388 ISSN 2453-8035 DOI: $10.1515 /$ lart-2016-0008 
London: Continuum International Publishing Group.

Margolin, U. (1999). Of what is past, is passing, or to come: temporality, aspectuality, modality, and the nature of narrative. In Herman, D. Narratologies: new perspectives on narrative analysis. Ohio State University: Columbus Press, p. 42-66.

Momaday, N.S. (1969). The way to rainy mountain. New Mexico: University of New Mexico Press.

Momaday, N.S. (1996). Interview. Sun Valley: Idaho.

Momaday, N.S. (1998). House made of dawn. N.Y.: Harper and Row Publishers.

Propp, V. (2011). Morphology of the folktale. Austin: University of Texas Press.

Sandner, D. (1991). Navajo symbols of healing. Rochester, VT: Healing Arts Press.

Semino, E. (2008). Metaphor in discourse. New York: Cambridge University Press.

Silko, L.M. (1986). Ceremony. N.Y.: Penguin Books.

Sotirova, V. (2016). The Bloomsbury companion to stylistics. Bloomsbury:

Bloomsbury Publishing Plc.

Silverman, K. (1983). The Subject of Semiotics. New York: Oxford University Press.

Sternberg, M. (1990). Telling in time (I): chronology and narrative theory. In Poetics Today, 11, p. 90-148.

Sternberg, M. (1992). Telling in time (II): chronology, teleology, narrativity. In Poetics Today 13, p. 463-541.

Sternberg, M. (2003). Universals of narrative and their cognitivist fortunes (I). In Poetics Today, 24, p. 297-395

Toelken, B. (1976). Seeing with a native eye: how many sheep will it hold. In Native American literatures (2004). New York-London: Continuum, p. 26-27.

Vinogradov, V.V. / Виноградов В.В. (1963). Стилистика. Теория поэтической речи. Поэтика. Москва: АН СССР. 


\begin{tabular}{|l|l|}
\hline \multicolumn{2}{|c|}{ Contact data } \\
Svitlana Volkova \\
Doctor of Science \\
(Philology), Associate \\
Professor, Kherson State \\
University, Ukraine \\
Universitetskastr., 27 \\
Kherson73000 \\
e-mail: \\
volkovasvetlana@yandex.ua
\end{tabular}

\section{Résumé in English}

Study of the cognitive dimensions of stories and storytelling has become an important subdomain within the field of narrative analysis. The paper focuses on the narrative perspective of interpreting the ethno-cultural meanings hidden in the characters of prosaic texts written by contemporary Amerindian writers (N.S. Momaday, Linda Hogan, Leslie Silko and others). The main idea raised in their works is to highlight ethno-cultural traditions, values, ceremonies and understanding the world. For that they try to thrust their narratives into contention between linear time (chronological time past, presence, future), sacred time (synchronic time - mythological interventions into history), and memory (fragmented and nonsequential or syncretic time - or meaning begetting thought that can imagine connections). The beliefs and worldview of Amerindian people are coded in verbal signs of literary texts. Decoding these signs is possible by means of cognitive semiotic (sign - symbol - image) and cognitive narrative (interpreting image as symbolic sign) approach to their interpretation. So, the main interest is paid to the reverse perspective as a narrative technique of interpretation the central character as ethno-cultural symbol. Reverse perspective may be regarded in two dimensions: as author's technique and as an analyst's technique. Author's intention is to show his main character as ethno-cultural hero and the task of the interpreter is to "reread" this ethno-cultural meaning in the text. To reveal/understand or extract the sense of the knowledge transformed by means of main 
character descriptions the following cognitive operations should be applied: mapping (projecting one motif into another), construal (selecting the appropriate structural possibility among various alternatives), inferences (making the conclusions from a set of premises), focusing (giving prominence to some selected elements of a scene and downplaying others). Linguistic and cognitive mechanism of reverse perspective is activated by means of lexical triggers expressed by words denoting ethnocultural symbols.

Keywords: Amerindian prosaic texts, cognitive semiotic, cognitive narrative, linguistic and cognitive mechanism, linguistic and cognitive procedure, narrative perspective, reverse perspective.

\section{Résumé in German}

Die Analyse der kognitiven Dimension einer Erzählung ist ein wichtiger Aspekt der narrativen Analyse geworden. Der vorliegenden Artikel fokussiert auf die ethnokulturellen Bedeutungen der Hauptfiguren in den Werken der gegenwärtigen amerindischen Autoren N. Scott Momaday, Linda Hogan und Leslie Marmon Silko. In ihren Werken zeigen diese Autoren die ethnokulturelle Bedeutung von Traditionen und Zeremonien, Werten und Religionsweltanschauung des amerindischen Volkes. In den Werken spielen verschiedene Zeitdimensionen eine Rolle: Linearzeit (Vergangenes, Gegenwärtiges, Zukünftiges), Sakralzeit (mythologische Interventionen in die historische Darstellung), und Gedächtnis (fragmentarische Einfügung der autobiographischen Erinnerungen). Die Weltanschauung und Religion der Amerindianen sind in den Wortzeichen kodiert. Diese Zeichen können analytisch interpretier werden mit Hilfe eines kognitiv-semiotisches Verfahren (vom Zeichen bis zum Symbol und zur Gestalt) und eines kognitiv-narratives Verfahren (die Gestalt als symbolisches Zeichen). Dieser Artikel fokussiert auf das narrative Verfahren der Rückperspektive (zu unterscheiden von Retrospektion). Dieses Verfahren macht es für den Autor möglich, die Hauptfigur eines Textes als ethnokulturelles Symbol, als 
Helden, zu gestalten. Zugleich ist sie für die narrative Analyse ist ein Mittel zur Entdeckung der ethnokulturellen Bedeutungen, die die Wortzeichen enthalten. Für die Analyse der Textinhalte werden folgende kognitive Verfahren eingesetzt: Mapping (Projektion eines Motivs auf ein anderes), Construal (Auswahl der geeigneten Struktur), Inferenz (Schlussfolgerungen), und Focusing (bestimmte Elemente werden hervorgehoben). Der Artikel veranschaulicht das Schema des linguokognitiven Mechanismus der Rückperspektive. Der Mechanismus wird durch lexikalische Trigger, die auf ethnokulturelle Symbole hinweisen, aktiviert.

Schlüsselwörter: amerindische Prosawerke, kognitiv-semiotisches Verfahren, kognitiv-narratives Verfahren, linguokognitiver Mechanismus, narrative Deutungsperspektive, Rückperspektive, Mapping, Akzentuierung, Inferenz, Konstruieren, Trigger der Rückperspektive

\section{Résumé in French}

Le centre de l'intérêt scientifique de cet article est la perspective narrative de l'interprétation des sens ethnoculturels, cachée dans les caractères des héros principaux des prosateurs amérindiens contemporains (Navarr Scott Momadey, Linda Khogan, Lesly Sylko et d'autres). L'idée maîtresse des œuvres des auteurs nommés est de montrer la valeur ethnoculturelle des traditions et des cérémonies du peuple amérindien, ses priorités de valeur, ses conseptions religieuses du monde. Ainsi les auteurs recourent aux procédés narratifs différents tels que la perspective inverse, le procédé qui permet de faire la liaison entre les trois dimensions temporaires, utilisées par les écrivains amérindiens: le temps linéaire (le passé, le présent, le futur), le temps sacral (des interventions mythiques dans la narration historique) et la mémoire (les inclusions fragmentaires des mémoires autobiographiques). Dans l'interprétation de la cohérence de la narration, le procédé de la perspective inverse représente juste un tel moyen qui aide non seulement à unir dans le texte des événements narratifs différents d'après la thématique et le contenu, mais aussi à interpréter le sens et la valeur de cette 
union narrative. Les conceptions des Amérindiens, leurs croyances sont codées dans des signes linguistiques. Leur décodage est effectif du point de vue de l'accès cognitif et sémiotique (du signe au symbole et à l'image) et du point de vue de l'accès cognitif et narratif (l'image est comme un signe symbolique). Au cours de l'interprétation de l'image artistique, basée sur la perspective inverse, une telle image est traité comme un symbole ethnoculturel. Pour éviter la confusion entre le flash-back et la perspective inverse dans ce travail on a montré la différence d'emploi de ces deux techniques narratives. Dans le mécanisme de la perspective inverse agissent les opérations cognitives suivantes: planning (projection d'un motif sur un autre), construction (choix de la structure de la connaissance), inférence (réinterprétation des faits), focalisation (accentuation sur un des éléments de la structure). Le mécanisme linguistique et cognitif de la perspective inverse s'activisent par des triggers lexicaux, exprimés par les mots qui désignent des symboles ethnoculturels.

Mots-clés: textes amérindiens des œuvres en prose, cognitif et sémiotique, cognitif et narratif, mécanisme linguistique et cognitif, perspective narrative, perspective inverse, triggers de la perspective inverse, planning, construction, inférence, focalisation.

\section{Résumé (in Russian)}

В центре научного интереса представленной статьи находится нарративная перспектива интерпретации этнокультурных смыслов, заложенных в образах главных героев современных америндских прозаиков (Н.С. Момадей, Линда Хоган, Лесли Силко и др.). Основной идеей произведений перечисленных авторов является попытка показать этнокультурное значение традиций и церемоний америндского этноса, его ценностные приоритеты, религиозные мировоззрения и миропонимание. Для этого авторы прибегают к различным нарративным приемам, к числу которых мы относим обратную перспективу: прием, который позволяет провести связь между тремя временными измерениями, к которым прибегают америндские писатели: линейное время 
(прошедшее, настоящее, будущее), сакральное время (мифологические интервенции в историческое повествование) и память (фрагментарные включения автобиографических воспоминаний). В интерпретации нарративной когезии повествования приём обратной перспективы выступает именно тем средством, которое помогает не только объединить разные по тематике и содержанию нарративные события внутри общей ткани текста, но и интерпретировать смысл и значения такого нарративного объединения. Мировоззрение америндцев, их верования, закодированы в словесных знаках. Их декодирование считается эффективным с позиций когнитивно-семиотического (от знака к символу и образу) и когнитивно-нарративного (образ как символический знак) подходов. В ходе интерпретации художественного образа с позиции обратной перспективы такой образ трактуется как этнокультурный символ. В статье представлена схема лингвокогнитивного механизма обратной перспективы, который активируется на основе лингвокогнитивных процедур ассоциации, аналогии, компрессии, редукции, противопоставления.

Key words: америндские прозаические тексты, когнитивно-семиотический, когнитивно-нарративный, лингвокогнитивный механизм, нарративная перспектива, обратная перспектива.

Article was received by the editorial board 28.08.16;

Reviewed 9.10.16. and 16.10.16.

Similarity Index 38\%. 